\title{
OZONE DISINFECTION OF COMMUNITY PHARMACIES DURING THE COVID-19 PANDEMIC AS A POSSIBLE PREVENTIVE MEASURE FOR INFECTION SPREAD
}

Piotr Merks ${ }^{1,2,3}$, Urszula Religioni ${ }^{4}$, Krzysztof Bilmin $^{1}$, Joanna Bogusz ${ }^{5}$, Grzegorz Juszczyk ${ }^{6}$, Agnieszka Barańska ${ }^{7}$, Robert Kuthan $^{1,8}$, Ewelina Drelich ${ }^{2,3}$, Marta Jakubowska $^{3}$, Damian Świeczkowski ${ }^{3,9}$, Artur Białoszewski1 ${ }^{10}$, Miłosz Jaguszewski ${ }^{3,9}$, Edwin Panford-Quainoo ${ }^{11}$, Regis Vaillancourt ${ }^{12}$, Dariusz Białoszewski ${ }^{13}$

${ }^{1}$ Cardinal Stefan Wyszyński University, Warsaw, Poland

Faculty of Medicine, Collegium Medicum

${ }^{2}$ Collegium Medicum in Bydgoszcz, Bydgoszcz, Poland

Department of Pharmaceutical Technology, Faculty of Pharmacy

${ }^{3}$ Polska Grupa Farmaceutyczna S.A., Łódź, Poland

${ }^{4}$ Warsaw School of Economics, Warsaw, Poland

Collegium of Business Administration

${ }^{5}$ National Institute of Public Health - National Institute of Hygiene, Warsaw, Poland

${ }^{6}$ Medical University of Warsaw, Warsaw, Poland

Department of Public Health

${ }^{7}$ Medical University of Lublin, Lublin, Poland

Department of Computer Science and Medical Statistics with the Studio of Remote Learning

${ }^{8}$ Medical University of Warsaw, Warsaw, Poland

Chair and Department of Medical Microbiology

${ }^{9}$ Medical University of Gdansk, Gdańsk, Poland

First Department of Cardiology

${ }^{10}$ Medical University of Warsaw, Warsaw, Poland

Department of Prevention of Environmental Hazards and Allergology

${ }^{11}$ Liverpool School of Tropical Medicine, Liverpool, United Kingdom

${ }^{12}$ Children's Hospital of Eastern Ontario, Ottawa, Canada

${ }^{13}$ Medical University of Warsaw, Warsaw, Poland

Department of Rehabilitation, Faculty of Medical Sciences

\begin{abstract}
The COVID-19 pandemic is currently one of the major global health and economic challenges. An efficient method for reducing the transmission of the virus is a still unmet medical need. Existing experimental data have shown that coronavirus survival is negatively impacted by ozone, high temperature, and low humidity. Therefore, it is feasible to use area ozonation in pharmacies - the front line of the healthcare system. Nevertheless, further work is needed to evaluate the effectiveness of ozone disinfection to reduce the transmission of this virus in pharmacies, hospitals, and other public environments. Med Pr. 2021;72(5):529-34

Key words: coronavirus, pandemic, ozone, disinfection, pharmacist, pharmacy

Corresponding author: Piotr Merks, Cardinal Stefan Wyszyński University, Faculty of Medicine, Collegium Medicum, Wóycickiego 1/3, 01-938 Warsaw, Poland, e-mail: piotrmerks@googlemail.com Received: November 21, 2020, accepted: April 21, 2021
\end{abstract}

\section{INTRODUCTION}

Currently, one of the global challenges is to reduce the healthcare and economic burden of severe acute respiratory syndrome coronavirus 2 (SARS-CoV-2) which causes the coronavirus disease (COVID-19) pandemic [1]. Specifically, one of the priorities is to reduce the spread of the virus in public places which, on the one hand, are critical in terms of maintaining normal life for the society but, on the other hand, face an increased risk of SARS-CoV-2 infection. One type of such places is a pharmacy.

As pharmacy is often the first point of contact for people who have cold or flu symptoms, and the front 
line of the whole healthcare system, it can be an important source of transmission of SARS-CoV-2. A person infected with SARS-CoV-2 who is looking for a remedy probably comes to the pharmacy during the highest contagious period of the disease (the first few days) [2,3].

Although physical distancing, protective gear, and interior design modifications introduced to pharmacies are important preventive measures, the possibility of a virus carrier (either a patient or a family member) coming to the pharmacy (especially for overthe-counter medications) is still high. Therefore, there is a strong need to prevent the spread of SARS-CoV-2 in pharmacies.

Due to the lack of approved protocols, there are no air disinfection strategies available for inactivating airborne viruses during viral outbreaks. Despite the fact that UV light, ozone, and disinfecting agents have been tested for airborne phage and virus inactivation [4], none of them has led to the establishment of standardized air disinfection protocols. However, ozone disinfection could be one of the possible approaches as it is one of the recommended methods in area disinfection where people with a confirmed SARS-CoV-2 infection are hospitalized [1]. Moreover, the unique physicochemical and biological properties of ozone, including strong biocidal and oxidizing properties, suggest a possible role in the therapy of SARS-CoV-2 infection either as a complementary or an adjunct to standard disinfection regimens. Additionally, ozone can be used in the disinfection of many different types of SARS-related viruses [5].

\section{METHODS}

In the article, the authors discuss the feasibility of using ozone for the disinfection of pharmacy areas and the effectiveness of the above method in combating SARSCoV-2. A search of literature available in PubMed, Google Scholar and MEDLINE was conducted using the following terms: "COVID-19," "SARS-CoV 2," "coronavirus," "ozone," "ozonation," "ozone disinfection" and "ozone treatment" in combination with "pharmacy," "community pharmacy" and "pharmacist" as keywords. Articels with no limitation regarding the date of publication were extracted, following which the authors analyzed the title and abstract of each searched article and, based on that, they identified the content suitable to their review. In the next step, the articles were analyzed thoroughly and all relevant content was included in the review.

\section{RESULTS}

\section{The mechanism of action} and current applications of ozone

Ozone interferes with the bacterial cell envelope through oxidation of biomolecules and leads to cell disintegration. It also effectively destroys biofilms produced by some bacteria [6]. The basic mechanism of the virucidal effect of ozone is damage to viral capsid, as a consequence of which the virus is unable to attach to the cell membrane and penetrate inside the cell [7]. A study by Sato [8] showed that ozone was effective against several types of viruses and suggested that ozone disinfection could be used as a disinfection method.

Ozone is widely used in disinfection, i.a., in water intended for human consumption and pool water [9]. Additionally, ozone is used as a decontamination agent, e.g., in the food production industry, pharmaceutical industry in herbal medicines manufacturing [10], and in the decontamination of anti-cancer drugs [11]. Ozone disinfection has also been tested on antibiotic-resistant bacteria, including clostridioides difficile, methicillin-resistant staphylococcus aureus, and vancomycin-resistant enterococci, which pose a serious risk to hospitalized patients [7]. Finally, low ozone concentrations can be used to treat the air in naturally ventilated hospital rooms, providing an additional tool for hospitals that do not have heating, ventilation and air conditioning systems $[12,13]$. It is worth to note that the effect of ozone disinfection may vary depending on room humidity. The severity of the virucidal effect of ozone is observed with increasing relative air humidity [13].

\section{The efficacy of ozone in reducing an airborne transmission of viruses}

Ozone reduces the spread of viruses in the air through the reaction with organic matter, i.e., molds, fungi, and their spores, viruses, bacteria, allergens and mites, and eventually destroys them [5]. By breaking down the ozone molecule, an oxygen molecule is released and it neutralizes chemical compounds as a result of joining them. Unfortunately, the virucidal effect of ozone in the gas phase is not adequately confirmed in the literature. In addition, apart from the length of contact, it depends primarily on the ozone concentration level in the room air [14].

The values of concentration and contact time needed to inactivate the virus at $90 \%$ are $0.34-1.98 \mathrm{~min}-\mathrm{mg} / \mathrm{m}^{3}$. The virus inactivation at the level of $99 \%$ occurs at the values of $0.80-4.19 \mathrm{~min}-\mathrm{mg} / \mathrm{m}^{3}$ [14]. However, due 
to the reactions of the virus with other microorganisms in the environment and chemical air pollutants, it may turn out that a higher dose of ozone will be required to obtain a similar degree of virus inactivation under real conditions.

Obtaining a sufficiently high concentration of ozone in the air depends on the technical capabilities of the ozone generator and relative humidity $(\mathrm{RH})[13,15]$. In a study conducted by Dubuis et al. [13], to test the effectiveness of air disinfection with ozone and $\mathrm{RH}$ in the inactivation of airborne viruses, 4 phages $(\varphi \mathrm{X} 174$, PR772, MS2, and $\varphi 6$ ) and 1 eukaryotic virus (Murine norovirus $1[\mathrm{MNV}-1]$ ) were exposed to low ozone concentrations and different humidity levels for 10-70 min. The results show the effectiveness of air disinfection for phage and inactivation of MNV-1 using low ozone concentrations, $1.13 \pm 0.26 \mathrm{ppm}$, and $0.23 \pm 0.03 \mathrm{ppm}$, respectively, at various relative humidity levels and times exposure up to $70 \mathrm{~min}$. The greatest effect on the inactivation of $\varphi$ X174, MS2 and MNV-1 was observed for 40 -minute exposure at $85 \%$ relative humidity. These findings suggest that ozone used at a low concentration is a powerful disinfectant for airborne viruses when combined with a high relative humidity.

\section{The anti-viral activity of ozone in the context of SARS-CoV-2}

The virucidal effectiveness of ozone is determined by the properties of the virus particles and ozone concentration. It is possible that enveloped viruses, including SARS-CoV-2, may be more susceptible to the effects of ozone $[13,16]$. The virus detected in Wuhan and the SARS virus belong to the Coronaviridae family [16]. The ability of ozone to inactivate cysteine-dependent proteins has been reported as the effect of ozone on cysteine-dependent papain, which is believed to deactivate the enzyme by oxidizing the active sulfhydryl group to sulfonate or sulfenic acid [17].

Coronaviruses (including SARS-CoV-2) have cysteine-rich regions in their structures, which can be used in ozone (or other oxidants) therapy. Cysteine is an amino acid with a thiol group. Intact cysteine is necessary for the virus to be active. It is very susceptible to oxidation, which impairs its biological activity in proteins, affecting their structure. Thus, cysteine oxidation by a free oxygen radical released from the unstable ozone molecule can lead to "off" protein activity and virus deactivation. In a similar mechanism, the virus on the surface undergoes natural deactivation by oxygen from the air; however, the degradation of thiol groups by oxygen is a slow process (as is known, the virus can remain active on the surfaces for quite some time). In contrast, a free oxygen radical released from the unstable ozone molecule leads to immediate oxidation of thiol groups after contact.

Also, the coronavirus peak protein is rich in tryptophan [18], which is second to cysteine in terms of susceptibility to oxidation [19]. There is also evidence of using ozone as a therapeutic agent against COVID-19 in the clinical setting (the so-called ozone therapy) [20]. Case reports of patients who benefited from this method of disinfection are already available [21].

There is a lot of data about the airborne transmission of the novel coronavirus SARS-CoV-2. In recent studies, researchers have confirmed that SARS-CoV-2 can be transmitted via air, especially in inadequately ventilated rooms (areas). It was also noted that higher ozone concentrations in the air can contribute to reducing the spread of the novel coronavirus this way [22].

\section{The advantages and limitations of ozone disinfection}

The advantages of ozonation include effectiveness, security, comprehensiveness, speed, operation, economy, and availability. Ozone quickly fills the entire room, penetrates the structure of upholstered furniture, reaches all nooks and crannies, including those hard to reach, which cannot be decontaminated by other methods. Ozone disinfection in sufficiently high concentrations removes odors, kills pathogenic microorganisms such as mites and other allergens, bacteria, molds, viruses, fungi, germs, and other microorganisms [23,24]. After disinfection, the room and its equipment are clean and free of harmful germs. Moreover, ozone is an unstable gas and it degrades very quickly [25]. The rooms are ready for use when ozone concentration in the indoor air is below the maximum safe value [26]. After ozonation, unpleasant smells are destroyed, including musty, mold, tobacco smoke, sweat, animals and burning [23,24], and viruses, bacteria and other pathogenic microorganisms are killed [27]. Ozonation also protects against pests such as mosquitoes, cockroaches, ants, moths, and rodents $[23,24]$.

Ozone already at low concentration displays bactericidal properties. It has been shown that ozone is 50 times more effective and has 3000 times faster action, than chlorine (the most popular disinfectant) [28]. Ozone disinfection is a relatively cheap method of disinfecting areas that, after ventilation, can be used immediately. After applying ozonation, there is no need to purchase and use disinfectant or bactericidal chemicals, 
because ozone removes and does not mask unpleasant odors and pathogenic microorganisms. Furthermore, data from a preclinical toxicology study have confirmed the safety of ozonation.

In this study, the effect of ozone exposure in rats was investigated. Ozone was produced by a generator at a concentration of $0.05 \mathrm{ppm}$ and experimental animals were exposed for 3-24 h/day over 14 and 28 days. No harmful effects of ozone on rats were found. The amount of food consumed, weight gain, as well as the macroscopic and microscopic image of the lungs, did not differ between the examined groups [21].

However, the problematic side of disinfecting spaces by ozonation comprises ambiguities regarding airborne concentrations of ozone needed for its effective virucidal activity. Moreover, the obtained effect is only temporary [29] and ozone is significantly harmful to human health $[23,24]$, also in the form of ozone residues and damage to room equipment (especially susceptible materials containing rubber), so there is a need to remove them from the room before ozonation. Ozone disinfection is safe only if the service is performed by following the appropriate rules and adhering strictly to the instructions and specification of the particular ozone generator that is being used.

Another limitation of ozone disinfection is that it does not protect re-penetration into the room of SARSCoV-2 particles, whose potential source is every infected person entering the room, even when one is unaware of the infection. This can occur even shortly after ozonation (several hours). Moreover, at ozone biocidal concentrations, due to its oxidizing properties, it exerts an outstanding, irritating effect on the conjunctiva and the mucous membrane of the respiratory tract, which may result in burning pain and redness of the conjunctiva, coughing, wheezing, or difficulty breathing. Additionally, ozone can cause deterioration of lung function in a spirographic examination, an increase in the incidence and severity of asthma attacks in people suffering from this disease, and the severity of discomfort in people with concomitant respiratory and cardiovascular diseases $[23,24]$.

\section{CONCLUSIONS}

Coronaviruses (including SARS-CoV-2) have cysteine-rich regions in their structures, which can be used in ozone (or other oxidants) therapy. An intact cysteine is necessary for the virus to be active. It is very susceptible to oxidation, which impairs its biological activity in proteins, affecting their structure. Thus, cysteine oxidation by free oxygen radical released from the unstable ozone molecule can lead to "off" protein activity and virus deactivation. In a similar mechanism, the virus on the surface undergoes natural deactivation by oxygen from the air; however, the degradation of thiol groups by oxygen is a slow process (as is known, the virus can remain active on the surfaces for quite some time). In contrast, a free oxygen radical released from the unstable ozone molecule leads to immediate oxidation of thiol groups after contact. Nevertheless, further work is needed to evaluate the effectiveness of ozone disinfection to reduce the transmission of this virus in pharmacies, hospitals, and other public environments.

\section{REFERENCES}

1. Xiao-Wei X, Xiao-Xin W, Xian-Gao J, Kai-Jin X, LingJun Y, Chun Lian M, et al. Clinical findings in a group of patients infected with the 2019 novel coronavirus (SARSCov-2) outside of Wuhan, China: retrospective case series. BMJ 2020;368:m606.

2. Centers for Disease Control and Prevention [Internet]. The Centers [cited 2020 May 4]. 2020. Coronavirus Disease 2019 (COVID-19) - Transmission. Available from: https:// www.cdc.gov/coronavirus/2019-ncov/prepare/transmission.html.

3. Li P, Fu J, Li K, Chen Y, Wang H, Liu L, et al. Transmission of COVID-19 In The Terminal Stage Of Incubation Period: A Familial Cluster. Int J Infect Dis. 2020;96:452-3, https:// doi.org/10.1016/j.ijid.2020.03.027.

4. Gérard V, Sunnen MD. SARS and ozone therapy: Theoretical considerations [Internet]. [cited 2020 July 19]. Available from: http://www.triroc.com/sunnen/topics/sars.html.

5. Elvis M, Ekta JS. Ozone therapy: A clinical review. J Nat Sci Biol Med. 2011;2(1):66-70, https://doi.org/10.4103/09769668.82319.

6. Bialoszewski D, Pietruczuk-Padzik A, Kalicinska A, Bocian E, Czajkowska M, Bukowska B, et al. Activity of ozonated water and ozone against Staphylococcus aureus and Pseudomonas aeruginosa biofilms. Med Sci Monit. 2011; 17(11):BR339-44, https://doi.org/10.12659/MSM.882044.

7. Sharma M, Hudson JB. Ozone Gas Is an Effective and Practical Antibacterial Agent. Am J Infect Contro. 2008; 36(8):559-63, https://doi.org/10.1016/j.ajic.2007.10.021.

8. Sato H, Wananabe Y, Miyata H. Virucidal effect of ozone treatment of laboratory animal viruses. Jikken Dobutsu. 1990;39(2):223-9, https://doi.org/10.1538/expanim1978.39.2_223. 
9. Schmitt A, Mendret J, Roustan M, Brosillon S. Ozonation using hollow fiber contactor technology and its perspectives for micropollutants removal in water: A review. Sci Total Environ. 2020;729:138664, https://doi.org/10.1016/ j.scitotenv.2020.138664.

10. Dal Molim Ghislenia D, de Souza Bragaa M, Satiko Kikuchia I, Braşoveanub M, Nemţanub MR, Kamal D, et al. The Microbial Quality Aspects and Decontamination Approaches for the Herbal Medicinal Plants and Products: An in-Depth Review. Current Pharm Design. 2016;22:4264-87, https://doi.org/10.2174/138161282266 6160623070829 .

11. Tsukamoto A, Ishiwata S, Kajimoto A, Murata R, Kitano R, Inoue $\mathrm{T}$, et al. Application of ozone gas for decontamination of nucleoside anticancer drugs. J Pharm Health Care Sci. 2016;2:26, https://doi.org/10.1186/s40780-016-0058-3.

12. Yao M, Zhang L, Ma J, Zhou L. On airborne transmission and control of SARS-Cov-2. Sci Total Environ. 2020;731:139178, https://doi.org/10.1016/j.scitotenv.2020. 139178 .

13. Dubuis ME, Dumont-Leblond N, Laliberté C, Veillette M, Turgeon N, Jean J, et al. Ozone efficacy for the control of airborne viruses: Bacteriophage and norovirus models. PLoS One. 2020;15(4):e0231164, https://doi.org/10.1371/ journal.pone.0231164.

14. Learning from SARS: Preparing for the Next Disease Outbreak: Workshop Summary. Institute of Medicine (US) Forum on Microbial Threats; Knobler S, Mahmoud A, Lemon S, et al., editors. Washington (DC): National Academies Press (US); 2004.

15. Tseng $\mathrm{C}, \mathrm{Li} \mathrm{C}$. Inactivation of surface viruses by gaseous ozone. J Environ Health. 2008;70(10):56-62.

16. Wang L, Wang Y, Ye D, Liu Q. Review of the 2019 novel coronavirus (SARS-CoV-2) based on current evidence. Int J Antimicrob Agents. 2020;55(6):105948, https://doi. org/10.1016/j.ijantimicag.2020.105948.

17. Dussault PH, George AD, Trullinger TK. Peroxides as oxidative enzyme inhibitors: Mechanism-based inhibition of a cysteine protease by an amino acid ozonide. Bioorg Med Chem Lett. 1999;9:3255-8, https://doi.org/10.1016/ S0960-894X(99)00563-6.

18. Broer R, Boson B, Spaan W, Cosset FL, Corver J. Important role for the transmembrane domain of severe acute respiratory syndrome coronavirus spike protein during entry. J Virol. 2006;80:1302-10, https://doi.org/10.1128/JVI.80. 3.1302-1310.2006.

19. Sharma VK, Graham N. Oxidation of amino acids, peptides and proteins by ozone: A Review. Ozone Sci Engineer. 2020;32:81-90, https://doi.org/10.1080/019195 10903510507.
20. Zheng Z, Dong M, Hu K. A preliminary evaluation on the efficacy of ozone therapy in the treatment of COVID-19. J Med Virol. 2020;92:2348-50, https://doi.org/ 10.1002/jmv.26040.

21. Cestonaro LV, Marcolan AM, Rossato-Grando LG, Anzolin AP, Goethel G, Vilani A, et al. Ozone generated by air purifier in low concentrations: friend or foe? Environ Sci Pollut Res Int. 2017;24(28):22673-8, https:// doi.org/10.1007/s11356-017-9887-3.

22. Martínez-Sánchez G ,Schwartz, Di Dionna V. Potential Cytoprotective Activity of Ozone Therapy in SARSCoV-2/COVID-19. Antioxidants. 2020;9(5):389, https:// doi.org/10.3390/antiox9050389.

23. United States Environmental Protection Agency. National Risk Management Research Laboratory [Internet]. Washington: U.S. Environmental Protection Agency; 1995 [cited 2020 Dec 20]. Ozone Generators in Indoor Air Settings. Available from: https://nepis.epa.gov/Exe/ZyNET.exe/ 9100FX29. TXT? ZyActionD=ZyDocument $\&$ Client $=$ EPA $\&$ Index $=1995+$ Thru $+1999 \&$ Docs $=\&$ Quer $y=\&$ Time $=$ $\&$ EndTime $=\&$ Search Method $=1 \&$ TocRestrict $=\mathrm{n} \&$ Toc $=$ $\&$ TocEntry $=\&$ QField $=\& Q$ Field Year $=\&$ QFieldMonth $=$ $\& Q$ FieldDay $=\&$ IntQFieldOp $=0 \&$ ExtQFieldOp $=0 \& \mathrm{Xml}$ Query $=\&$ File $=$ D $\% 3 A \% 5$ Czyfiles\%5CIndex\%20Data\% 5C95thru99\%5CTxt\%5C00000026\%5C9100FX29.txt \&User $=$ ANONYMOUS\&Password $=$ anonymous \&Sort Method $=$ h\%7C- \&Maximum Documents $=1 \&$ Fuzzy Degree $=0 \&$ Image Quality $=$ r75g8/r75g8/x150y150g16/ i $425 \&$ Display $=\mathrm{hpfr} \&$ DefSeek Page $=\mathrm{x} \&$ Search Back $=$ ZyActionL\&Back $=$ ZyActionS\&BackDesc $=$ Results $\% 20$ page $\&$ MaximumPages $=1 \& Z y$ Entry $=1 \&$ SeekPage $=x \& Z y$ PURL.

24. United States Environmental Protection Agency. National Risk Management Research Laboratory [Internet]. Washington: U.S. Environmental Protection Agency; 1996 [cited 2020 Dec 20]. Air Quality Criteria for Ozone and Related Photochemical Oxidants. Available from: https://cfpub.epa.gov/ncea/risk/recordisplay.cfm?deid= 149923.

25. Hill AG, Rice RG. Historical background, properties and applications. In: Rice RG, editor. Ozone treatment of water for cooling application. Ann Arbor, MI: Ann Arbor Science Publishers; 1982. p. 1-37.

26. Dyas A, Boughton BJ, Das BC. Ozone Killing Action Against Bacterial and Fungal Species; Microbiological Testing of a Domestic Ozone Generator. J Clin Pathol. 1983;36:1102-4, https://doi.org/10.1136/jcp.36.10.1102.

27. National Research Council (US) Safe Drinking Water Committee. Drinking Water and Health: Volume 2. Washington (DC): National Academies Press (US); 1980. 
28. Martuzzi M, Mitis F, Iavarone I, Serinelli M. Hecdcalth impact of PM10 and ozone in 13 Italian cities. Copenhagen: World Health Organization; 2006.
29. Valdés H, Sánchez-Polo M, Rivera-Utrilla J, Zaror CA. Effect of Ozone Treatment on Surface Properties of Activated Carbon. Langmuir. 2002;18(6):2111-6, https:// doi.org/10.1021/la010920a.

This work is available in Open Access model and licensed under a Creative Commons Attribution-NonCommercial 3.0 Poland License - http://creativecommons.org/licenses/by-nc/3.0/pl/deed.en. 